On a tout lieu de croire que les professeurs qui participeront, soit comme conférenciers, rapporteurs ou présidents, seront indemnisés par leur Université. Vers le ler mai de chaque année, lors de l'allocation définitive des fonds, tout argent non utilisé sera alloué aux jeunes membres de l'Association qui ne participeront pas comme conférenciers, rapporteurs ou présidents. Nous soulignons ce point aux organisateurs du programme qui doivent aviser les participants de la date limite.

Prière d'adresser toute demande d'allocation à Madame Joan Pond, Administrateur, Association canadienne de Science politique, Carleton University, Ottawa (Ontario) K1S 5B6, avant le 15 avril 1982.

Votre lettre de demande doit mentionner : (1) que vous avez solicité une allocation de votre Université; (2) le montant de toute allocation que vous pensez recevoir par ailleurs; (3) votre titre académique; (4) si vous allez participer activement à la conférence (présentation d'une communication ...).

\title{
1982 Essex Scholarships
}

The Canadian Political Science Association receives a grant from the Social Sciences and Humanities Research Council of Canada to permit three Canadian scholars to attend the Summer School in Social Science Data Analysis and Collection held each year at The University of Essex, Colchester, England. The course is sponsored by The Department of Government at Essex and by the European Consortium for Political Research. It is very highly regarded and is attended by Western Europeans and some North Americans.

The Association offers three scholarships of around $\$ 2,000$ each to cover travel, fees, and accommodation for the obligatory four-week stay. The programme takes place in July and August of each year. The scholarships are open to graduate students and to faculty, and Essex offers courses for a whole range of participants from neophytes to advanced.

We invite enquiries and will provide those interested with specific information about the programme, as well as information on how to make a formal application. Please write, before October 31, 1981, to Mrs. Joan Pond, Administrator, Canadian Political Science Association, Carleton University, Ottawa, Ontario, K1S 5B6.

\section{Bourses d'Etudes 1982 à The University of Essex}

L'Association canadienne de Science politique reçoit tous les ans une subvention du Conseil de recherches en Sciences humaines du Canada pour envoyer trois chercheurs canadiens au séminaire d'été de The 